IBIMA Publishing

Journal of Innovation \& Business Best Practice

http://www.ibimapublishing.com/journals/JIBBP/jibbp.html

Vol. 2013 (2013), Article ID 245614, 11 pages

DOI: $10.5171 / 2013.245614$

Research Article

\title{
Measurement of Innovation in the Czech Republic
}

\author{
Žaneta Rylková and Barbora Antonová
}

School of Busienss Administration in Karvina, Karvina, Czech Republic

Correspondence should be addressed to: Žaneta Rylková; rylkova@opf.slu.cz

Received 7 September 2012; Accepted 24 June 2013; Published 28 September 2013

Academic Editor: Daniela Hincu

Copyright (C 2013 Žaneta Rylková and Barbora Antonová. Distributed under Creative Commons CCBY 3.0

\begin{abstract}
Development has become an important determinant for companies, but also necessity. In order to be organization successful, there is necessary to pay attention to innovation activities. The paper is based on primary and secondary research. From the survey which was carried out in the Department of Management and Business of School of Business Administration in Karviná in the Czech Republic, in the year 2011, the paper points out the contribution of innovation and innovative business, which have a significant impact on the competitiveness of the company, or region. In order to evaluate the survey there was used program SPSS. Innovative activities should generally be regarded as the key area of economic development. Therefore the paper also deals with business innovation and innovation performance in the Czech Republic and with innovation metrics for innovation measurement which are available in European Union and available in the Czech Republic.
\end{abstract}

Keywords: Innovation, performance, measurements, innovation business.

\section{Introduction}

Innovation would not be an everyday event, but such an event or fact, which has the ability to redefine the scope and boundaries - opening up new opportunities and it is also a challenge for existing players, in order to change something in light of the new conditions. In the above mentioned example there agree Foster (2002), Evans and Hamel (2000). This is also the central theme of Schumpeter's original theory of innovation, where innovation is understood as a process of "creative destruction". In the same sense as Schumpeter (1950) there also speak authors Abernathy (1985), Boisot (1995). From the definition of innovation, innovation can be understood as a general activity necessary for the survival and growth of the organization. Innovative business is then understood as a set of business activities specializing in the continuous realization of innovative activity.

The aim of the paper is to evaluate innovative the innovation performance of the Czech Republic on the basis of primary and secondary research. The paper also indicates areas which are important to monitor and evaluate need in the context of the current time. This paper is supported by the Student Grant System of Silesian University under number SGS/9/2012.

Cite this Article as: Žaneta Rylková and Barbora Antonová (2013), "Measurement of Innovation in the Czech Republic," Journal of Innovation \& Business Best Practice, Vol. 2013 (2013), Article ID 245614, DOI: 


\section{Innovative Companies in the Czech Republic}

From the research of dissertation Rylkova (2010) it was possible to evaluate innovative enterprises in the Czech Republic (see table 1). Most of today's successful innovation is a combination of innovation, where combined products are the output of joint innovation activities carried out by individual members of networks. In the Czech Republic was found dissertation Rylkova (2010) that only $13 \%$ of selected sample (300 organizations) from the Czech Republic consider cooperation of small and medium sized companies as the main factor of innovation background in the company. As for SME's cooperation with other firms, only $34 \%$ asked cooperate on new product or process development.

In the period 2008-2010 from the total number of technically innovative enterprises only $34.2 \%$ enterprises collaborated on the introduction of technical innovations with an external partner. Large technically innovative enterprises cooperated more $(62.1 \%)$ than medium (45.9\%) and small enterprises (25.1\%).

For the technically innovative firms there were the most common co-operating partners in innovation suppliers of equipment, materials, components or software (mentioned by $23.9 \%$ of firms). Important role as a cooperating partner played clients or customers (19.2\%). The least frequent trade partner for technical innovation there were government and public R \& D institutions (6.9\%). Top ranking partners with whom technically innovative enterprises cooperated is the same in size groups of enterprises. For all size groups of enterprises there prevails the product innovation over process innovation.

Table 1 evaluates the development of innovative enterprises in the Czech Republic.

Table 1: Innovative Enterprises in the Czech Republic

\begin{tabular}{|l|l|}
\hline Development of innovative enterprises & Share grows \\
\hline $\begin{array}{l}\text { Enterprises with technical innovation } \\
\text { (product or process innovation) }\end{array}$ & Share decreases \\
\hline $\begin{array}{l}\text { Enterprises with non-technical innovation } \\
\text { (organizational or marketing innovation) }\end{array}$ & Share grows \\
\hline Manufacturing sector & Higher innovation performance \\
\hline Service sector & Lower innovation performance \\
\hline Large enterprises & Most innovatively active \\
\hline Midle-sized enterprises & Less innovatively active \\
\hline Small enterprises & Least innovatively active \\
\hline Cooperation & Low level \\
\hline
\end{tabular}

\section{Own Research}

Department of Management and Business of School of Business Administration in Karvina, Silesian University in Opava conducted survey under the title "Adaptability of SMEs in the current economic conditions in the crisis years 2007 - 2010" (2011). The research took place in the summer semester of the year 2011 with the help of full-time and distance students. Interpreted sample characterizes the state in 206 companies in the Czech
Republic. The questionnaire was completed by the student on a personal meeting with a manager of company. The questionnaire survey included the following categories: A. Identification of the company (11 questions), B. Strategic and Project Management (9 questions), C. Risk and crisis management (11 questions), D. Personnel Policy (7 questions), E. Production, services and innovative activities ( 9 questions), F. Use of grants and subsidies (8 questions), G. Energy savings and renewable energy (6 questions), $\mathrm{H}$. 
Identification and intermediate student opinion survey (6 questions).

In order to evaluate the survey there was used SPSS 11.5 program. Outputs were achieved with using several methods, for the purposes of this study there were selected three methods: Rotated Component Matrix (factor loadings after rotation, arranged by size), Communalities (part of variability explained by variables common factors) Correlation Matrix (mutual dependence of two questions).

One of the objectives of the research carried out by the department was to analyze and evaluate whether firms innovated in the years 2007 - 2010, and what types of innovations where the most frequently. As for the questionnaire survey there was formulated hypothesis $(\mathrm{H})$ : Innovation activities in this period are concentrated primarily on product product or service.

The results showed that $70.1 \%$ of enterprises (206 companies) didn't innovate, $29.9 \%$ of firms innovated. Only 12 companies innovated something different and the rest truly innovated the product. The hypothesis was confirmed and is supported by the following table 2 .

Table 2: Types of Innovation

\begin{tabular}{|l|l|l|l|l|l|}
\hline \multicolumn{2}{|l|}{} & Frequency & Percent & Valid Percent & $\begin{array}{l}\text { Cumulative } \\
\text { Percent }\end{array}$ \\
\hline Valid & Without innovation & 136 & 65,7 & 72,7 & 72,7 \\
\hline & Goods & 13 & 6,3 & 7,0 & 79,7 \\
\hline & Goods, services & 3 & 1,4 & 1,6 & 81,3 \\
\hline & Goods, technology & 1 &, 5 &, 5 & 81,8 \\
\hline & Services & 20 & 9,7 & 10,7 & 92,5 \\
\hline & Services, quality & 2 & 1,0 & 1,1 & 93,6 \\
\hline & Services, technology & 1 &, 5 &, 5 & 94,1 \\
\hline & Quality & 4 & 1,9 & 2,1 & 96,3 \\
\hline & Quality, technology & 1 &, 5 &, 5 & 96,8 \\
\hline & Design & 2 & 1,0 & 1,1 & 97,9 \\
\hline & Technology & 4 & 1,9 & 2,1 & 100,0 \\
\hline & Total & 187 & 90,3 & 100,0 & \\
\hline Missing & System & 20 & 9,7 & & \\
\hline Total & & 207 & 100,0 & & \\
\hline
\end{tabular}

From the questionnaire survey conducted by the Department of Management and Entrepreneurship there was possible to point out areas that can have a high impact on the success of the organization.

Using SPSS program 11.5 there was found this structure of questions which attract the most links with other questions and are most responsible for the results that came out after the evaluation of specified number (sample) of questionnaires. Questions correlation coefficient higher than 0.5 was found 36 , but in order to remained the contribution clear and concise, the table number 20 involved only 12 of the most important issues with a correlation coefficient higher than 0.7.

From the results in the table 3 it may be inferred that the areas can have the greatest impact on the speed of adaptability of companies to changes and development. Innovation, performance measurement and strategic planning are factors that specifically help companies to survive. 
Table 3: The Most Important Questions - TOP 12 (Communalities)

\begin{tabular}{|lll|l|l|}
\hline & & & Initial & Extraction \\
\hline 1. & Product and service innovation & (E1) & 1,000 & 0,809 \\
2. & Written procuration & (C8) & 1,000 & 0,805 \\
3. & Changing the view on strategic planning & (B5) & 1,000 & 0,804 \\
4. & Areas of changes in products and services & (E2) & 1,000 & 0,779 \\
5. & Measures in practice & (C10) & 1,000 & 0,777 \\
6. & Renewable Energy & (G3) & 1,000 & 0,748 \\
7. & Written risk analysis & (C7) & 1,000 & 0,737 \\
8. & Types of innovation & (E8) & 1,000 & 0,731 \\
9. & Performance measurement & (C9) & 1,000 & 0,725 \\
10. & Return & (C1) & 1,000 & 0,721 \\
11. & Number of employees & (A7) & 1,000 & 0,715 \\
12. & Profit & (C3) & 1,000 & 0,708 \\
\hline
\end{tabular}

\section{Businesses and Measurement of Innovation Performance}

According to Jiménez, Sanz-Valle (2011) most of the broad empirical studies on the relation between innovation and performance provide evidence that this relation is positive ([Bierly and Chakrabarti, 1996], [Brown and Eisenhard, 1995 and [Caves and Ghemawat, 1992]; e.g. Damanpour, 1991; e.g. [Damanpour and Evan, 1984], [Damanpour et al., 1989], [Hansen et al., 1999], [Roberts, 1999], [Schulz and Jobe, 2001], [Thornhill, 2006], [Weerawardenaa et al., 2006] and [Wheelwright and Clark, 1992]). However, as Simpson et al. (2006) point out, innovation is an expensive and risky activity, with positive outcomes on firm performances but also with negative outcomes, such as increased exposure to market risk, increased costs, employee dissatisfaction or unwarranted changes. In addition, some studies arrive at conflicting conclusions. For instance, Wright et al. (2005), using a sample of small businesses, find that product innovation does not affect performance in benign environments, but has a positive effect on performance in hostile environments.

Question is on what basis the innovation activities of firms are evaluated at all in the world. We can probably say that the answer to this question may be a guideline to the microeconomic competitiveness. It would probably be archaic noting only the total profit in companies. Much more interesting are the various indicators, which were derived from profit. One from them is the return on equity (ROE) or return on assets (ROA). We can say that use of financial indicators is not enough nowadays to evaluate and measure innovative activities.

Boston Consulting Group in its report Measuring Innovation 2006 deals with problems of measuring innovation and the use of innovative metrics in companies. Boston Consulting Group notes that innovation constitutes the inputs, processes and outputs, which correspond to the view that are provided in the paper, too. All these parts should then be measured.

It is also important to remember whom evaluation serves and also how large a sample of measures is monitored. Business management can make own indicators, it is therefore the internal evaluation. In this relatively simple evaluation there is usually not a problem collecting data. The disadvantage is the inability to compare with other companies. Conversely, if the evaluation serves to external entities, there is assessed a larger group of companies (external evaluation). This group could be for example a certain territory of companies or companies with a similar focus. In this case it is much difficult to 
obtain the willingness of stakeholders to provide data. The necessary data can sometimes be undetectable from the ground that they are not monitored and tracked in a company.

According to Rejeb, Morel-Guimaes (2008) literature attests of researches in the field of innovation capacity evaluation (for a company or a country) (Furman, 2003). These approaches are generally based on the evaluation of the innovation process outcomes and of the resources devoted to it. All these statements may be considered through three analytical levels (setting aside the individual and collective cognitive level) (Boly, 2004):

Level A: The permanent and global innovation management of the company. This level integrates all the strategic tasks, the organization of new projects launching and the improvement of innovation management practices.

Level B: The outcomes or inputs of a particular project. This level is characterized by a limited period and is concerned with the transformation of an idea up until an innovative product.

Level C: The material characteristics of the innovative product resulting from the new product development process. This level represents the artefact of Level B. This approach suits our special interest in establishing links between evaluation and operational management tasks. The evaluation of Level $\mathrm{C}$ is very common in engineering through the definition of the future specifications of the innovative product and its relating performances.

According to Rejeb, Morel- Guimaes (2008) Literature is mostly concerned with Level B evaluation. Many authors propose approaches to determine the balance between the outcomes and inputs of innovation. Generally, financial and commercial variables are taken into account (Griffin and Page, 1996; Huang et al., 2004; Kangmao et al., 2005). Financial evaluations are based on classical ratio including financial margins and returns on investment (Crepon et al., 2000). Moreover, specific financial criteria dedicated to innovation resources are suggested: they generally measure time and cost development (Grant and Pennypacker, 2006). Marketing variables include qualitative and quantitative aspects, such as new market shares and customer satisfaction (this last example is dedicated more to product's Level $\mathrm{C}$ than to the project's Level B). Strategic considerations, such as competitive advantage, are integrated to evaluate the balance between outcomes and inputs. Several authors (Archibugi and Pianta, 1996; Abraham and Moitra, 2001) add technological criteria, such as the number of patents, to conduct this evaluation.

\section{Metrics within the Enterprise}

Innovative capabilities are crucial for maintaining, respectively increasing the competitiveness of companies. Innovative capabilities are the property of companies but they do not define the innovative activities of the companies. These can be identified only by comparing two or more companies in a specific market context.

Innovative capabilities are a kind of background for the emergence of innovations. Measuring innovation capacity can then be done by measuring the assumptions, that means inputs (factors of production) in the innovation process (associated with finding and collecting innovative ideas and ending with investment in worker education and in research and development). It is obvious that some conditions are relatively easily measurable (quantity), others very heavily (quality). 
Table 4: Measurement of Innovative Capabilities

\begin{tabular}{|c|c|}
\hline Individual indicator & Measure \\
\hline $\begin{array}{l}\text { Spending on science and } \\
\text { research }\end{array}$ & $\begin{array}{l}\text { - The research and development expenditures for a given } \\
\text { period }\end{array}$ \\
\hline $\begin{array}{l}\text { Capital invested in the } \\
\text { acquisition of production } \\
\text { equipment }\end{array}$ & $\begin{array}{l}\text { - Investment in new equipment and depreciation schedule } \\
\text { - Investment in employee training }\end{array}$ \\
\hline $\begin{array}{l}\text { Education and training of } \\
\text { employees }\end{array}$ & $\begin{array}{l}\text { - Expenditure of company for staff training } \\
\text { - Percentage of employees trained in the area of } \\
\text { innovation }\end{array}$ \\
\hline $\begin{array}{l}\text { Capital invested in the } \\
\text { acquisition of know-how }\end{array}$ & $\begin{array}{ll}\text { - } & \text { Purchase of knowledge (licence, utility models) } \\
\text { - } & \text { Patents } \\
\text { - } & \text { Purchase of software }\end{array}$ \\
\hline Other indicators & $\begin{array}{l}\text { - Percentage of staff time devoted to innovation } \\
\text { - Number of innovative ideas }\end{array}$ \\
\hline
\end{tabular}

For measuring inputs there are most frequently used (according to the experience of enterprises surveyed in the dissertation Rylkova (2010) operating costs, capital expenditures, number of employees allocated to specific activities related to innovation. For measuring process it is used metric of the duration of the change the idea in the idea realization that means the movement within innovation process from one stage to the next one. Table 4 presents the most common individual indicators measuring innovation capabilities.

Innovation performance (implementation of innovation) stands up to the very end of the innovation process. For measurement it is necessary to understand and describe the whole innovation process and to identify factors that may affect the ultimate realization of innovation. Measuring output includes for example number of newly listed products, changes in market share, growth in sales and profit growth from sales of innovative products.

Innovation performance follows the innovative activities of the company but as innovation activity it is not the property of the company. It is again the result of the innovation process and arises from interactions among competing firms in a given market situation. Innovation performance is generally considered as a crucial component of long-term competitiveness of countries and regions.

According to Košturiak, Chal' (2008), it is useful to use the following indicators of innovation performance:

- Success of innovations: the number of successful projects to the total number of initiated innovative projects.

- Effectiveness of innovations: the real contribution of projects to the total cost of the project.

- Time of innovation: the average time implementation of innovative projects.

- Return on Innovation: the period during which benefits from an innovative project reach the project costs.

- Return on Innovation: return on investment in innovation.

- Total expenditure on innovation as a percentage of sales.

From my own knowledge, it is possible the indicators of innovation performance summarize in table 5 . 
Table 5: Measurement of Innovation Performance

\begin{tabular}{|l|l|}
\hline Individual indicator & Measure \\
\hline Realized innovation & $\bullet$ Number of implemented innovations during period \\
\hline Success of innovation & $\bullet \begin{array}{l}\text { Number of soccessful projects to the total number of } \\
\text { initiated innovative projects }\end{array}$ \\
\hline Time of innovation & $\bullet$ Average time implementation of innovative projects \\
\hline Acquired patents & $\bullet$ Numberof patents for a certain period \\
\hline Economic indicators & $\begin{array}{l}\text { - Return on Innovation } \\
\text { - Total expenditure on innovation as a of sales } \\
\text { - Real contribution of the project to the overall cost of the } \\
\text { project }\end{array}$ \\
\hline
\end{tabular}

\section{Complex Metrics}

Individual indicators measuring innovation or innovative performance are insufficient in themselves, they always look from one angle on the issue of innovation and it depend on the company what types of indicators will be chosen. Complex metrics are a possible alternative which contains several individual indicators to evaluate all businesses of a state.

According to Wits (2012) currently, a large portion of the economy of developed countries is based on non-material resources such as services. In general, there is a positive correlation between the share of IP (e.g. patents, royalties, license fees, R\&D expenses) of a country's Gross Domestic Product (GDP) and the GDP per capita itself. Macroeconomists show that strengthening patent protection and generating revenue from IP (i.e. royalties and license fees income) in a country, increases this country's economic growth.

\section{Pan-European Innovation Survey}

Standardized metrics for measuring innovation in the EU and EFTA (European Free Trade Association) is a pan-European innovation survey (CIS), which is designed in order to be possible to compare the results obtained among businesses, industries and ultimately among states. Measuring innovation according to the CIS methodology the Czech Statistical Office conducts by using TI questionnaires. Current TI 2005 questionnaire (Questionnaire on innovations in 2005) is based on the Oslo Manual in 3rd revision and of the Eurostat harmonized guidelines for statistical surveys in the EU CIS 4 for the reference period 2002-2004. Due to revisions in the Oslo manual follows the questionnaire TI 2005 in the company four types of innovation - product, process, organizational and marketing. Questionnaire TI 2005 is a combined metric tracking innovation inputs and outputs. The areas are covering four types of innovations thematically, the size and scope of business, innovation activities, innovation funding, information resources, innovative collaboration, the results of innovative activities, limiting factors of innovation. From comparison of the collected information in an enterprise and from aggregate data for the Czech Republic it can be tracked according to various aspects track innovation capacity and performance. Comparisons in among companies in a field (summary data are classified according to the Classification of Economic Activities (NACE), company size, etc.) is due to the broad base of European data measured by a standardized metric of the biggest benefits of the metrics from a business perspective.

\section{Map Prerequisites for Innovation in the Enterprise}

Compared to the measurement of innovation performance where the results are easier to quantify, the measurement of innovation capabilities is much more in the analysis of the qualitative variables. An important role plays promotion of innovation by management, the climate in the company, management systems, 
employee motivation etc. 1 The metric is based solely on analysis of the qualitative variables. Questionnaire assesses six areas of the business environment: strategy and planning, marketing, production, products and organization, quality and environment, logistics, organization and human resources.

\section{The European Innovation Scoreboard}

Effort of a comprehensive evaluation of innovation is the European Innovation Scoreboard (EIS), which tries to capture innovative capacity and performance, but it is primarily focused on assessing the potential innovations of individual states of European Union.

EIS includes individual indicators and aggregate indicator called Summary Innovation Index (SII - Summary Innovation Index). Number and structure of individual indicators is growing and changing with each issue of EIS. In the year 2008 EIS included seven dimensions (human resources, financial support, investment firms, cooperation and business, unfinished outputs, innovative firms, economic effects), which were divided in 29 individual indicators.

Summary Innovation Index (Summary Innovation Index, further SII) is currently composed of 24 indicators, which are organized into three main groups (activators, corporate activities, outputs) and eight categories. Due to changes in the methodology (a significant change in years 2008 and 2010) as well as changes in the monitored parameters it is not correct to formulate definite conclusions on the basis of changes in the position of our economy at a time, so the paper is focused on the assessment of the position of the Czech Republic in the latest edition IUS (Innovation Union Scoreboard 2011).

Construction of the index for 2010 and 2011 involved newly category "Open, Excellent and Attractive Research Systems" ("An open, high-quality and attractive

${ }^{1}$ Processed by University of West Bohemia Plzen in the project: SME - Cooperation in Innovations research systems") into a group of activators and the group is containing the following three indicators:

- International scientific co-publications per million population (joint international scientific publications per million inhabitants)

- Scientific publications among the top $10 \%$ most cited publications worldwide as $\%$ of total scientific publications of the country (share of scientific publications in $10 \%$ of the world's most cited publications in the total number of scientific publications)

- Non-EU doctorate students as\% of all doctorate students (the proportion of doctoral students from countries outside the EU, the total number of doctoral students).

The category of innovative activators includes human and external financial resources and new indicators which measure the international competitiveness in science and research (see above). The category of corporate activities includes: inner investment of companies, innovative ties, cooperation, entrepreneurship and protection of industrial property. The category of innovation outputs includes indicators related to innovative firms (such as the number of innovative small and medium sized enterprises) and economic effects of innovation.

The construction of the Summary Innovation Index (SII) is based on data of the latest statistics from Eurostat and other internationally recognized sources that are for compared countries available at the time of the analysis. Specifically, the SII for year 2011 was based on data of the year 2007 for one indicator (share of scientific publications in $10 \%$ of the world's most cited publications in the total number of scientific publications) from the year 2008 for 9 indicators - for example, a group of innovators is an indicator of the share of small and medium-sized enterprises - SMEs which have introduced product, process, organizational or marketing innovation, from the total number of SMEs. In the 
group of economic effects is involved the "pre-crisis status" indicator exemplified share of innovative new products to market and new to firm to the total return. Innovative behavior of firms and countries in crisis and "post-crisis" conditions reflects in the index the state through the capture of three indicators for the year 2009 and 11 indicators for the year 2010 . As a result of methodological limitations IUS 2011 does not capture some aspects of the recent changes in innovation performance, neither the impact of policies aimed at promoting innovations that have been introduced in recent years. Concurrently the index can fully not capture the impact of the financial and debt crisis on innovation performance.

According to the SII the Czech Republic ranks third position in the group of countries known as moderates innovators with SII value slightly below the EU-27 in recent years. Moderate innovators are countries reaching 50 to $90 \%$ of the EU-27. The average innovation performance is measured using a composite indicator that takes into account the "innovative results" of countries based on 24 indicators, zero is the worst possible result, maximal possible result is assigned by value 1 . In the year 2011 the average innovation performance reflects the real innovation performance in $2009 / 2010$ - the reason is the time delay in disclosure of relevant statistical data.

Countries belonging to the innovative leaders (innovation leaders) are reaching at least $20 \%$ higher innovation performance than the average for the EU27 , the so-called followers of innovation (innovation followers) are those whose innovation performance is within $10 \%$ below average to $20 \%$ above the EU-27 average. Performance of Moderate Innovators group of countries is lower than in the EU-27, but reaches higher values than corresponds to $50 \%$ of the EU-27. Countries with lower innovation performance belong to the group Modest Innovators.

Czech Republic belonged according to rating dynamics of innovation performance (calculated on the basis of the development of the indicators making up the SII in the previous five years) with an average annual growth of $4.8 \%$ among well above average among countries (average annual growth rate of the EU-27 amounted to $1.8 \%$ ) in the year 2009. In the year 2010, the average annual growth in innovation performance of Czech Republic was lower - only $2.6 \%$, while the average annual growth rate of EU countries amounted only $0.85 \%$. Thanks to economic growth in the year 2010 (mainly due to positive developments in the manufacturing and service industries), the current average annual growth rate of the innovation performance of the Czech Republic rose to $3.2 \%$. While in the year 2010 the value for the EU-27 was $0.85 \%$ in the year 2011 average growth rate dropped to $0.33 \%$ due to the impact of the economic crisis. In both years, the resulting growth rate is positively influenced by the development of indicators in open, excellent and attractive research systems, the negative impact was observed in case of indicators of corporate investment, in usage of venture capital (there decreased indicator - amount of funds designated as venture capital to HDP3) and in innovators group (decrease of innovative small and medium sized enterprises).

\section{Conclusion and Discussion}

Problem of all available metrics is according to Hadraba (2006) that measuring innovation should be carried out effectively, efficiently (must bring relevant information to the corporate management) and economically (must be done at a reasonable cost). Individual indicators generally meet the requirement of economy, but rarely effectiveness, as they focus on innovation from a too narrow view. Comprehensive indicators then fight with economy and practicality sometimes because they contain subjective indicators or indicators difficult to estimate (for example percentage of time dedicated by management on innovative activities instead of resolving operational issues). Individual financial indicators (or their various combinations), which would seem to be suitable for easy traceability and fairly wide angle, they have not good informative value. (see Valenta) 
According to Rylková (2010) the innovation effect should include measurable results, balanced cost of capital, it should include both qualitative and quantitative criteria, it is necessary to monitor the market position and create and develop a corporate culture which is opened to innovation.

Evaluation of companies (either internal or external) should mainly serve the company management, which should be reflected in the results of the evaluation of its other activities and possibly the best practices should be used elsewhere. In the case of an enterprise or small group of companies it is possible to implement and measure a set of quantitative criteria. In the case of a large group of companies in different industries with very different objectives it is necessary to take a broad approach to the assessment.

Despite all the shortcomings, the use of complex innovative metrics seems most appropriate when we compare companies within countries or when we compare different countries, but the complex innovative metrics are general. Whether they are trying to measure innovation, performance, or combinations they are always exploring innovative process from multiple views and from multiple angles. It tries to give an overall view of the study area, which individual innovative metrics can not offer.

The paper introduced innovative metrics which are available in European Union and available in the Czech Republic. The question for discussion and future research is: Do there exist any other complex innovative metrics which are used in countries on the macro level? What measures should companies evaluate within the innovation activities?

\section{Acknowledgment}

This paper is supported by the Student Grant System of Silesian University in Opava, School of Busienss Administration in Karvina, Czech Republic, under number SGS/9/2012.

\section{References}

Český statistický úřad. (2012). [Online], Inovační aktivity podniků v České republice v letech 2006 - 2008 a 2008 - 2010., [Retrieved September 22, 2012], Available: http://www.czso.cz

European Innovation Scoreboard. (2012). [Online], [Retrieved September 22, 2012], Available:

http://www.proinnoeurope.eu

Hadraba, J. (2006). K Problematice členění a Hodnocení Inovací, [Online], [Retrieved April 4, 2008], Available: http://www.svses.cz/akce/inovace/hadra ba.pdf

Jiménez, D. \& Sanz-Valle, R. (2011). "Innovation, Organizational Learning and Performance," Journal of Business Research 64 (4), 408-417 [Retrived December 2012].

Košturiak, J. \& Chal', J. (2008). 'Inovace vaše konkurenční výhoda!, Brno,' Computer Press, Czech Republic.

Rejeb, H. B., Morel-Guimaes, L. et al. (2008). "Measuring Innovation Best Practices: Improvement of an Innovation Index Integrating Threshold and Synergy Effects," Technovation, Volume 28, Issue 12, December 2008. p. 838-854.

Rylková, ̌. (2010). Metodika pro hodnocení uplatňování inovací v malých a středních podnicích. OPF, SU Karviná, Czech Republic. Dissertation.

Rylková, Ž. (2011). 'Analýza a hodnocení faktorů vedoucích k efektu inovace,' Karviná, Silesian Univerzity, Czech Republic.

Šebestová, J., Rylková, Ž., Pawliczek, A., Piszczur, R., Veselá, K. \& Antonová, B. (2011). 'Adaptabilita podnikání v reakci na turbulentní politicko-ekonomické prostředí a technologický pokrok v kontextu udržitelného rozvoje,' Research Report of Department - Pilot research. Karviná: Slezská univerzita v Oapvě, Obchodně podnikatelská fakulta v Karviné. 
Vacek, J. (2010). 'Hodnocení inovačního potenciálu firmy (manuál),' ZČU Plzeň [Online].

Available:www.kip.zcu.cz/USME/dotaznik. pdf,

http://www.kip.zcu.cz/kursy/imi/IMI2007 /IMI3_potencial.ppt

Wits, W. W. et al. (2012). "Toward Multidisciplinary Support Tools for Innovation Tasks," Procedia CIRP. Volume 2, 2012 p. 16 - 21. [Retrieved September 22, 2012] Available: http://www.sciencedirect.com/science/art icle/pii/S2212827112001333 